\title{
Political Humour in the Social Network Sites
}

\author{
Ayşe Aslı Sezgin \\ Correspondence: Ayşe Aslı Sezgin, Faculty of Economics and Administrative Sciences, Osmaniye Korkut Ata \\ University, Turkey
}

Received: May 23, 2018

doi:10.11114/smc.v6i1.3320

\author{
Accepted: May 29, 2018 \\ Online Published: May 29, 2018 \\ URL: https://doi.org/10.11114/smc.v6i1.3320
}

\begin{abstract}
"Social network sites" first began to be used as new tools of political communication during the 2008 Presidential Election in the United States, and their importance became even more apparent during the Arab Spring. In the course of this, the social network sites became a new and widely discussed channel of communication. In addition to its ability to bring together people from different parts of the world by removing any time and space barriers, creates a virtual network that allows individuals with shared social values to take action in an organized manner. Furthermore, this novel, versatile and multi-faceted tool of political communication has also provided a new mean for observing various aspects of social reactions to political events. Instead of voters expressing their political views through their votes from one election to the other, we nowadays have voters who actively take part in political processes by instantly demonstrating their reactions and by directly communicating their criticisms online.
\end{abstract}

Keywords: humour, humour theories, new media, politics, political humour, social network sites, social movements

\section{Introduction}

Social network sites are now being used by societies living in different regions of the world to criticize the political system they are living in. In addition to academic publications examining different aspects of social network sites, this study aims to investigate the role of social network sites in political communication using the element of humour. For this purpose, study provides informations on use of Internet Technologies relations between humour, culture, internet and new social movements at the outset.

At this point it would be appropriate to make the definiton of "social network sites." According to Boyd and Ellison (2007) networking emphasizes relationship initiation, often between strangers. Networking is possible on these sites. There are hundreds of social network sites supporting a wide range of interests and practices. These sites help strangers to connect based on shared interests, political views, activities (Boyd and Ellison, 2007) and also protests.

Depending on the active use of social network sites in daily living and political communication studies, it is possible to state that internet technologies that allow the use of these networks are used through different channels in these studies. The internet has become an indispensable tool, especially in the political communication studies of political actors. The political communication activities, which are realized by traditional methods, are replaced by flexible and decentralized structures that can reach a wider area, in parallel with the change in digital age (Meric, 20179.).

The effects of communication activities carried out via the internet, assessed under different headings including political communication, were determined. These can be stated as providing information; networking; special publishing to a target audience, performed in a more limited area; enacting; encouraging participation; bypassing traditional media (Meric, 2017).

In addition to the above mentioned effects, it is possible to itemize the potential effects of internet communication on political communication as follows:

- Being cost efficient

- Providing to establish direct connection between source and target

- Offering the opportunity of special message design to the target

Internet technologies placed in every moment of human life provided opportunity for new developments and created a different work area for many researchers in political communication area. In the $21^{\text {st }}$ century the increasing of social network sites such as facebook, twitter, instagram, spreaded on notebooks, tablets and mobile devices are new powerful 
communication tools capable of influencing users' opinions in the field of politics (Auer, 2011). New media-internet environment has rich research resource for the political communicators following technological progresses closely. As different from conventional media channels, its visual richness, and interactive environment, unlimited structure about space and time drew the attention of the users in all areas, by this way new media was started to use frequently by every section wanted to reach over large target groups. According to Fenton and Barassi, in recent years there have been a wide variety of examples of how social networking sites have simplified the growth and widening of public movements (2011).

The ability of new media as making people from every section heard and its structure providing opportunity to form the media content by coming out of the position as reader strengthen the role within democratic life process. A number of managements all around the world use internet in order to present much more opportunities to the citizens today. E-government services can be the example of these technologies. According to World Bank, these technologies can serve a variety of different ends: better delivery of government services to citizens, improved interactions with business and industry, citizen empowerment through access to information, or more efficient government management. The resulting benefits can be less corruption, increased transparency, greater convenience, revenue growth, and/or cost reductions. Internet is at the position of intermediary between the management and public about application, complaint and requests. Internet users who are both discussing and listening, publishing and reading are at the position of content provider and consuming this content (Sitembölükbaş1, 2003).

While internet is defined as communication environment of global system is also evaluated as a technological development as an intermediary in the formation of new citizenship - the term "citizenship" define as "the rights necessary for individual freedom" in this sentence- (Marshall, 2006). Ideological and cultural influences created by technology are carefully assessed by political actors (Timisi, 2003). In this position of internet within democratic life, its structure allowing message flow is effective. Internet has an environment providing opportunity related to freedom of expression, being open for the information source, the message itself and its sharing without depending on any central authority (Timisi, 2003).

Internet drawing the attention of political scientists in a short span of time started to reshape political science also covering political behaviour (Park, 2007). Politicians who want to reach much more people also started to feel the advantages of being in this new communication environment when they started to involve in virtual world of internet (Park, 2007). Relation between political communication and internet which started with web sites established during election periods was extended towards many different areas on the rate of technological progress. Studies extended from virtual network diaries to podcast drew attention mostly in social network sites at the axis of advantages related to interactive structure. One of reason behind politicians increasing usage of social network sites can be indicated as immediate feedback opportunity provided in the social network sites. In recent years, candidate websites and other internet-based innovations have altered political campaigns. Besides websites, blogs, podcasts, social network sites and Youtube also have become additional means to reach voters (Davis, et.al. 2009).

\section{Background}

It was observed by public opinion in all around the world that people coming together in social network sites turned this association into a power which may change political authorities especially in the recent times. Arab Spring, earlier on USA Presidential elections, Wall Street drew the attention of many academicians being interested in this aspect academically. When I look at the literature, I encounter with studies made on sociological, political, economic and similar areas. Especially in the studies researching the connection of new media with politics in all parts, social network sites movements considered as a result of democratic life will be analysed by considering the effects of cultural and humorous elements in this study.

In recent years, "Internet revolutions" experienced in Middle East, Spain (Indignados) and USA stand out as movements demonstrating the communicational power of the internet. Thanks to its quality to rapidly spread information among individuals, new media, allowed the necessary environment for protestors to deliver the protests to masses with the same pace (Wiersma, 2014). Internet's potential to overthrow authoritarian regimes was observed much clearer following the events experienced in Middle East. These last developments in Arab countries became sources to political communication research studies (Wilson and Dunn, 2011). Digital Activism Project, led by Prof. Philip N. Howard (University of Washington), and The Tahrir Data Project (Christopher Wilson) constitute examples for these.

Internet has a major role in politics of democratic states as well as authoritarian states. Internet has become an indispensible communication tool for democratic institutions and stands out with its effect to increase and diminish power (Morozov, 2012). New information and communication technologies (ICT) and also internet have profound implications for how political communication scholars conduct their work (Garrett et.al, 2012). According to the journal New Information and Communication Technologies and the Study of Political Communication, political communication researchers can use the substantial processing power of low-cost computersto conduct novel 
experiments utilizing unique manipulations. ICT provides new ways of collecting data about people's behaviour. Political communication researchers use new types of analysis for understanding audience characteristics such as social network sites analysis, automated textual analysis (Garrett et.al. 2012).

Internet should also deal with the aspect of its political participation deal. Political participation refers to all forms of involvement in which citizens express their political opinion and/or convey that opinion to political decision-makers. Using online communication tools is one of the innovative form of political participation (Vissers and Stolle, 2014). There is an assumption about that internet opens up opportunities for a completely newtype of engagement that is not practiced in the same way offline (e.g. use of humour in political postings; the visible support for social/political organizations, candidates, and specificsocial/political goals; wide-reaching mobilization campaigns) (Vissers and Stolle, 2014).

It was emphasized in many studies that the effect of social network sites environments considered as areas providing opportunity for the reestablishment of community in virtual environments is felt all around the world. As different from the studies sharing findings asserting that social network sites change and direct economy (Smith, 2009), reflection of regional, cultural elements from social network sites within the scope of the subject of humour will be analysed in this study. In this study, as different from the changes realized by social network sites in terms of culture, it is started from the thought related to its characteristic as gathering individuals together in terms of region and having different sharing content according to the geographies.

When I look at the political developments which realized all around the world in the recent period and social network sites were actively used, I can see that elements bringing people in different geographies together in social networking environments differentiate one another. Before Arab Spring, in the sharings of internet users living in the region, sharings related to longing had for a democratic life, critics about the problems emerged from gender discrimination drew attention.

\subsection{Humour, Culture and the Internet}

Across all the intellectual disciplines of the humanities and human sciences, sensitive people have always sought and understanding of the problem of humour. Humour is an inherently mysterious and interesting phenomenon which spread human life (Veatch, 1998).

Laugher has amused and puzzled philosophers since Plato and Aristotles. Like philosophy, psychology has a respectable tradition of humour research. According to Zijderveld, if there is a phenomenon that is truly social and solidly entangled in culture, it is humourand sociology has in relation with this concept. One of the main reasons may be the fact that sociology has been predominantly social problem oriented (Zijderveld, 1995). However, the importance of a social approach to humour sociologists have not studied humour with anything like the frequency of their collagues in psychology. The sociologist typically examines the social context of humour (Fine, 1983). Substantially, humour is a social phenomenon. Jokes and other humorous phrases are form of communication that is usually shared in social interaction. These humorous phrases are shaped by social and cultural themes. And the topics and themes people joke about are generally central to the social, cultural and moral order of a society or a social group (Kuipers, 2008). In recent years, internet especially social network sites, has become the new medium about sharing humour themes for these social groups.

The internet has become a major player in the production and distribution of humour. Social network sites are the new channels for transferring humour in societies. Comic texts and figures draw on prevalent ideologies stereotypes and cultural codes. Online humour is a relatively new phenomenon (Shifman and Lemish, 2010). Today it is possible to say that internet is the new medium of humour. Internet humour have differences with face to face humurous communication. Online humour in discussion groups have possitive effect on group solidarity and it has important role in identity information (Laineste, 2013). Internet also use visualisation which is the very efficient tool in getting a message. A great part of the internet is made up of visual communication. The internet users apply traditional expressions in their internet communication (Baran, 2012).

The range of topics that are used in humorous communication is very wide. Shifman transfer from Driessen (2007) listed six prominent domains of humour across the World. These are language, sex and gender, politics, ethnicity, religion and age. According to Shifman, these humour topics can be divided into two categories by Driessen (2004): Globally oriented - Locally oriented. After this division it is possible to say that humour is a universal phenomenon and it depends on culture as it relies on the symbols, stereotypes and codes specific to the place and the time of its creation (Shifman, 2007).

Humour play an important role in social change. The relation of the complex interaction between the socially specific and psychological aspects of humour is the individual social actor and his'her practice (Halsall, 2004). Internet and social network sites are the new media of this social change by expresing these practices. 
According to Shifman, Coleman and Ward (2007) the relationship between politics, humour and the internet can be analysed by two ways. First, I can say that online political humour as a political participation. Political participation is regarded as an instrumentalist activity. Secondly, online political humour in the context of game - playing.

\subsection{History of Social Movements}

Defining restlessness in social environments as problems, may be shown as the emerging point of social movements. The most important problem in emerging social movements, is foremost the members' or parties' of the movements belief towards the existence of a specific problem. Belief towards solutions and initiations produced against the problem being insufficient, is necessary for emergence of social movements. Adequate information about the problem and strengthening beliefs are important in terms of forming joint actions. Thus, social problems are socialized and movement is commenced (Kilic, 2002). Today, an innovation that attracts societies' political lives is politics' steer towards more flexible groups consisting of demonstrator women, religious and ethnical groups, environmentalists, peace defenders and interested citizens by new political actors. Existence of new political actors and them finding representative opportunities reveals democracy's aspect that provides everyone the opportunity to be involved. Especially student and worker uprisings, women independence movements, ecologic-environmental movements experienced in the late 1960s in Europe, reflects the differences emerged in demonstrations, opinions and organization structures. These movements defined as "new" attracted attention in fields that cannot be represented by political governments and parties and demands they do not include (Sanli, 2003)

Tatar (2013), who examined the old and new social movements under topics of participant profiles, organization structures and principles, values, emotions, tools used, method and purpose, stated that movements conducted by marginal groups that emphasize differences have replaced social movements based on social classes, participated by individuals with low levels of education. In his findings drawing attention to individual oriented, global and local social movements instead of leader oriented social movements, it is stated that emotions of exclusion and neglect overpower those of being battered. New social movements rising from environmental awareness, opposition to war and demand for peace, are conducted through mass communication tools and especially the Internet. New social movements with the purpose of rights, freedom and existentialism are now organized with virtual environment meetings.

It may be said that social movements revealed in different forms, purposes and levels depending on periodical changes in historical context, have been actualized in modern societies against social changes that begun with industrialization. It is observed that new social movements emerge in the cultural area as a social opposition (Erturk, 2011).

Hasdemir and Coskun have emphasized that social movements have the capacity to have communicational demonstrations within the world of social movements. New social movements rising on the notion of identity, have a transforming function in social life with the democratic dam that has been constructed (2008). Social movements that create an environment of creativity where differences clash, may seek to create a shared identity. Social movements may enable individual demands to become a collective will through their constructive power. When I look at the development of social movements in Turkey, besides leftist social movements examined in parallel to syndical movement development, it is possible to talk about Islamic and nationalist social movements as well. Social movements that came to being after the Constitution of 1961, continued their movement and organizational level until the period of the 1980 coup (Yildirim, 2012). In social movements where young participants' numbers grow in the new era, in the comparison of old and new in Turkey, inherency to society becomes prominent. Social movements emerge in different styles in every different society. For this reason in evaluation of social movements, conditions of every country should be evaluated differently and these conditions should be considered (Coskun, 2006). Description of "new" added to social movements can be explained with a reference made to the past. Social movements do not have static and unchangeable templates. I can say that new movements are about new perception to movements as well (Tatar, 2013). Internet's structure supporting political involvement proves its active role in identifying policies regarding establishment, governance and monitoring of social order, and in studies regarding decision making and application. New developments in communication technologies, spread of use of internet (Karacor, 2009), organization of social movements via internet brought a new perspective to political communication. New technologies used, new media, internet have an important role in new social movements and emergence and sustaining of such movements. Due to the world being a much more connected network compared to the past thanks to internet, sphere of influence of organizations are much broader. Associations established in the virtual world via social network sites, turns into social movements through associations on location. Movements starting in social network sites are seen as much more innocent and genuine. In cases where legal obligations are felt less and sanctions are not explicitly executed, social network sites have a much broader field of freedom (Tatar, 2013).

\subsection{New Social Movements and the Internet}

In this part of the study it would be appropriate to provide information about cultural dimension and impact of new 
technologies to social movements. Hart (1996) discusses the cultural dimension of social movements with a theoretical reassessment. According to him, social movements are laboratories for cultural processes and there are 5 topics that are central to understanding the cultural aspect of social movements: (1) what cultural elements -concepts, images etc.- in the cultural environments, (2) how the structures of these pre-exiting codes, (3) what cultural craft-work is done by movement participants, (4) how the cultural forms created within movements, (5) how these cultural forms affect public discourse and political events (Hart, 1996).

Researches about social movements can refine the relationship between cultural change and stasis because movements arise out of what is culturally given, but at the same time they are a major source of cultural change. According to Johnston and Klandermas (1995) form a systemic perspective, culture can be seen as a characteristic of a movement's environment that restrict its development and that describes what behaviors are statutory and acceptable. In an another perspective, it focuses on how cultural knowledge is performed, sometimes revealing that the dominant culture is riddled with gaps and discrepansies. Some researches assumed that there is a dynamic relationship between movements and culture. Social movements not only can arise from fractures in culture but also process culture insofar as they consume what is culturally given and produce changings of it (Johnston and Klandermans, 1995).

New social movements make a new social space that is filled by a dynamic interaction between different groups and organizations. They also generate collective identities, knowledge and information. According to Salter (2003) new social movements are precisely the bodies that perceive problems and push them on to the public agenda. The structure of the internet provides for new social movements being, processes information. Traditional media channels are simply not suited to such needs. New social movements may use the internet to support external activity, they may work within in the internet to create a foundation for movements and they have attempted to influence policy effecting the internet (Salter, 2003).

Castells (2012) mentioned about Arab Spring, Iceland's Revolution, Indignados in Spain and Occupy Wall Street in his book Networks of Outrage and Hope: Social Movements in the Internet Age. And according to him social movements are the producers of new values and goals around which the institutions of society ae transformed to represent these values by creating new norms to organize social life (Castells, 2012).

Today a good deal of civic discussion takes places on the internet, not only in obvious public forums and among varieties of online journalism, but also wtihin the large networking of activists and social movements. With the most recent information and communication technologies, citizen groups and social movements, like many other organizations are likely to reach a new level in the ways in which they mobilize, make coalitions, lobby, communicate and campaign (Donk, et.al. 2004). Consequently, it is possible to say that internet is the new medium for social movements. And these social movements can be called nonviolent way of struggle in some researches. According to Sharp (1990), nonviolent struggle is a political technique. This technique of action uses social, psychological, economic and political methods. The technique includes too many methods and these methods called weapons of nonviolent action. It is possible to say humour in politics is one of the weapons of nonvilonet struggle which is about psychological.

\subsection{Politics, Humour and Social Revival in Social Network Sites}

Despite theories suggested almost every period of philosophy research, a clear consensus has not been arrived about the definition of "humour" yet. Today, academic studies related to humour are not still considered as sufficient. Humour is sometimes evaluated within the working area of philosophy. However, interdisciplinary nature of humour provides opportunity about working on the aspects related to humour in the field of psychology, sociology, anthropology and literature. Most of researches about humour was interested in the question "What is humour?" Required and sufficient conditions which should be fulfilled in order to accept something as humour have been listed in some definitions about humour (IEP, 2014).

Humour has been assessed within the scope of four different theories analysed under the headings as superiority, contradiction, relief and game. According to superiority theory, the humour has the characteristic of making somebody think and criticise about the current situation and it includes superiority sentiment due to this characteristic. According to contradiction theory, the perception of contradiction is the essential condition required for originating humour. In relief theory, psychological process producing laughter has been discussed instead of finding the definition of context of humour. As independent from other theories trying to explain humour, game theory assessed humour as a category of humour (IEP, 2014).

According to Attardo (1994), a commonly accepted classification divides theories of humour into three groups: incongruity theories, hostility theories and release theories. The first authors generally associated with incongruity theories of humour are Kant and Schopenhauer. The earliest theories all mention the negative element of humour its aggressive side. Hobbes formulated most forcefully the idea that laughter arises from a sense of superiority of the 
laughter towards some object (Attardo, 1994). Superiortiy theory is among the oldest theory of humour dating back to Platon and Aristotle. The superiority approach is summarized in Thomas Hobbes' famous statement that "the passion of laughter is nothing else but some sudden glory arising from some sudden conception of some reputation in ourselves by comparison with he infirmity of others, or with our own formerly" (Martin, 1998).

Another attractive part of humour within the scope of politics studies is the usage of humour in resistance movement not containing violence against oppression. Many of studies are mentioned about the growing popularity of humour in the protest repertories of activists around the world. In some approaches, humorous protest actions are a part of the emerging creative tactics. These actions invented by a particular movement should be recorded to inspire critical reflection and innovation by other movements. On the other hand little attempt has been made to analyse how humour work as a method of a nonviolent action (Sombutpoonsiri, 2013).

Humour is special way of communication. It can be used to hurt or used make other people, like other methods or mediums for communication (Sorensen, 2014). In his Phd thesis Sorensen focuses on political humour. And according to him political humour aims to criticise power. Humour is a powerful resistance strategy against compelling oppression. In another study, Majken Jul Sorensen benefitting from the study of Michael Mulkay headed as Humour as a Serious Strategy of Nonviolent Resistance to Oppression, researches of Stephen Brigham about the dimension of humour exceeding rationality and the analysis of Gene Sharp having the title of The Politics of Nonviolent Action, has emphasized the advantage of humour used against oppression in the contrast between innocence and seriousness (2008). According to Sorensen, humour can be categorised under three headings when assumed as a resistance movement:

1. Humour may function as a tool for establishing relation with individuals remaining outside of the movement; provides aid and support.

2. Individuals can take strength from humour for resistance. Humour can be effective in establishing resistance culture.

3. Humour can be effective in the relation between parties (2008).

Nowadays new political participation methods are started to research in political science studies, and different participation method executed by young population. Political science mostly assumes teenagers as the most inexperienced group of age having the tendency to see politics as boring and irrelevant with their lives. Youth is a generation being much more inclined to new political participation methods (Kovacheva, 2014).

Influence of internet on political life also encouraged young population using it actively in this direction. Internet's way of this direction is inevitable as an indispensible communication tool in daily life. Political participation also gained a new dimension in the new public area created by means of internet (Kalkan and Akgün). Influence of internet of political area focused upon some matters of discussion. Some of them may be specified as accession, technological determinism, intellectual property, public area, localisation, gender and ethnical origin (Poster, 1997).

In the researches related to humour and politics relationship, I encountered caricature studies which the origin are dated back to Antique Rome. These drawings having idea and amusement together (Bayram, 2009) were being frequently used by referring to the political area especially to the leaders. Political leaders sometimes indicated this situation as the brightest period of their carriers. Drawing their own caricatures and having criticisms towards their ruling by means of these caricatures were sometimes considered as an indicator of popularity for them (Dmitriev, 2008).

\section{Conclusion}

The use of the Internet and therefore the use of social network sites has influenced many areas of public life. This influence is so strong that a generation can no longer sustain their daily lives without the internet. The social lives planned through the Internet and social media networks have rebuilt all areas of ordinary everyday life. Many activities such as shopping, joining social environments, communication and banking are being carried out through the network that surrounds this world. Social network sites have also begun to meet the social and psychological needs of the person facing the monitors. Political participation has also gained a different dimension in this new life.

Especially the new generation which is born in the digital era and is called as the digital generation actually found a new channel in the society where they are criticized as being apolitical. The social network sites, the digital genre, the apolitical label, its own interpretation has changed. This generation demonstrates its own reaction to the political life of commentary, through colorful and effective channels of communication offered by social media networks. Humor should also be considered as an important factor in this new interpretation. The approach to politics from a humorous point of view is now much more colorful and effective in the digital age.

This study is aimed to conduct a review of the relationship between political humor and social network sites, with the support of the literature. It is possible to state that a different approach to politics in the future will be developed and 
adopted by the digital generation with the help of humor, as a result of the work that emphasizes that humor has a much different dimension in social media than in the past and that this dimension is mostly under the influence of younger generation. The use of social network sites as an important channel in social movements in the different regions of the world and humor's coming into prominence in the sharings about the subject in recent years are important proof of this new and different approach.

\section{References}

Attardo, S. (1994). Linguistic theories of humor. New York: Mouton de Gruyter.

Auer, M. (2011). The policy sciences of social media. The Policy Studies Journal, 39(4), 709-736. https://doi.org/10.1111/j.1541-0072.2011.00428.x

Baran, A. (2012). Visual humour in the internet. 171-186. Retrieved from http://pascalfroissart.online.fr/3-cache/2012-baran.pdf

Bayram, Y. (2009). Türkiye'de siyasi karikatürün yeri ve 11 nci cumhurbaşkanlığı seçimine ilişkin siyasi karikatürlerin çözümlenmesi. Selçuk İletişim, 6(1), 107-123.

Boyd, D., \& Ellison, B. (2007). Social network sites: definiton, history and scholarship. Journal of Computer-Mediated Communication, 13(1), 210-230. https://doi.org/10.1111/j.1083-6101.2007.00393.x

Castells, M. (2012). Networks of outrage and hope: social movements in the internet age. UK: Polity Press.

Davis, R., Baumgartner, J. et.al. (2009). The internet in US election campaigns. A. Chadwick, P. Howard (Ed.). Routledge Handbook of Internet Politics (pp. 13-24). New York: Routledge.

Dmitriev, A. V. E. (2008). Humor and politics. Russian Social Science Review, 49(1), 53-89. https://doi.org/10.2753/AAE1061-1959440304

Donk, W., Loader, B., Nixon P., \& Rucht, D. (Ed.) Cyberprotest:new media, citizens and social movements (pp. 1-23). USA: Routledge.

Fenton, N., \& Barassi, V. (2011). Alternative media and social networking sites: the politics of individuation and political participation. The Communication Review, 14, 179-196. https://doi.org/10.1080/10714421.2011.597245

Fine, G. A. (1983). Sociological approaches to the study of humour. P. McGhee and J. Goldstein (Ed.), Handbook of humour research (pp.159-181). New York: Springer.

Garrett, K, Bimber, B. et al. (2012). New ICTs and the study of political communication. International Journal of Communication, 6, 214-231.

Halsall, G. (2004). Humour, history and politics. UK: Cmabridge University Press.

Hart, S. (1996). The cultural dimension of social movements: a theoretical reassessment and literature review. Sociology of Religion, 57(1), 87-100. https://doi.org/10.2307/3712006

Hasdemir, T., \& Coşkun, M. (2008). Kamusal alan ve toplumsal hareketler. Ankara Üniversitesi Siyasal Bilgiler Fakültesi Dergisi, 63(1), 121-149.

Johnston, H., \& Klandermans, B. (1995). The cultural analysis of social movements and culture. H. Johnston (Ed.), Social movements and culture (pp. 3-25). UCL Press.

Kalkan, D., \& Akgün, A. İnternet ve siyasal yaşam: literatür değerlendirmesi ve bir sentez arayışı.

Kovacheva, S. (2014). Gençlik siyasi katılım kalıplarını gençleştirecek mi? V. Yılmaz, D. Bahçeci (Ed.), Gençlerin siyasi katılımı (pp.13-29). İstanbul: Bilgi.

Kuipers, G. (2008). The sociology of humour. V. Raskin (Ed.), The primer of humour research, (361-399). Berlin: De Gruyter.

Laineste, L. (2013). Funny or aggressive? Failed humour in internet commnets. Electronic Journal of Folklore, 53, 29-46. Retrieved from http://www.folklore.ee/folklore/vol53/laineste.pdf.

Marshall, T. K. (2006). Citizenship and social class. C.Pierson and F. Castes (Ed.), The Welfare State Reader (pp.30-40). UK: Polity Press.

Martin, R. (1998). Approaches to the sense of humour: a historical review. W. Ruch (Ed.), The sense of humour (pp. 15-60). New York: Mouton de Gruyter.

Meriç, Ö. (2017). Çevrimiçi siyasal iletişim üzerine bir literatür değerlendirmesi. Selçuk İletişim, 9(4), 25-39.

Park, H. L. (2007). Internet effects on political participation: Digital divide, causality, and new digital divide. ProQuest. 
Poster, M. (1997). Cyberdemocracy: Internet and the publicsphere. Internet culture, 201-218.

Salter, L. (2003). Democracy, new social movements and the internet. M. Mc Caughey and M.D. Ayers (Ed.). Cyberactivism: online activism in theory and practise. (pp.117-145), USA: Routledge.

Sharp, G. (1990). The role of power in nonviolent struggle. USA: Lynne Rienner Publishers.

Shifman, L. (2007). Humour in the age of digital reproduction. International Journal of Communication. 1, $187-209$. Retrieved from http://ijoc.org/index.php/ijoc/article/view/11

Shifman, L., \& Lemish, D. (2010). Between femisim an fun(ny) mism. Information, Communication \& Society, 13(6), 870-891. Retrieved from https://doi.org/10.1080/13691180903490560

Shifman, L., Coleman, S., \& Ward, S. (2007). Online joking? Online humour in the 2005 UK general election. Information, Communication \& Society, 10(4), 465-487. Retrieved from https://doi.org/10.1080/13691180701559947

Sitembölükbaşı, Ş. (2003). İletişim teknolojisindeki yenilikler ve temsili demokrasinin geleceği. Gazi Üniversitesi İktisadi ve İdari Bilimler Fakültesi Dergisi, 5 (2), 193-213.

Smith, T. (2009). Social media revolution. International Journal of Market Research, 51(4), 559-561. https://doi.org/10.2501/S1470785309200773

Sombutpoonsiri, J. (2013). The use of humour as a vehicle for nonviolent struggle: Serbia's 1996-7 protests and otpar movement. Unpublished doctoral dissertation, Le Trobe University, Bundoora, Victoria, Australia.

Sorensen, J. M. (2008). Humor as a serious strategy of nonviolent resistance to oppression. Peace\&Change, 33(2), 167-190. https://doi.org/10.1111/j.1468-0130.2008.00488.x

Sorensen, J. M. (2014). Humoruus political stunts. Nonviolent public challenges to power. Doctoral dissertation, University of Wollongong, Australia.

Tatar, T. (2013). Yeni toplumsal hareketler ve küresel projeler. Ortadoğu Analiz, 5(57), 10-20.

Timisi, N. (2003). Yeni iletişim teknolojileri ve demokrasi. Ankara: Dost.

Veatch, T. (1998). A theory of humour. Humour II 161-215. Retrieved from http://www.juliegrenonmorin.com/medias/files/a-theory-of-humor.pdf

Vissers, S., \& Stolle, D. (2014). The Internet and new modes of political participation: online versus offline participation. Information, Communication $\quad \& \quad$ Society, $\quad 17(8) . \quad 937-955$. https://doi.org/10.1080/1369118X.2013.867356

Yıldırım, Y. (2012). Türkiyeli toplumsal hareketlerin dönüşümüne genel bir bakış. Eğitim Bilim Toplum Dergisi, 10(38), 8-32.

Zijderveld, A. (1995). Humour, laugher and sociological theory. Sociological Forum. 10(2), $341-345$. https://doi.org/10.1007/BF02095968

\section{Copyrights}

Copyright for this article is retained by the author(s), with first publication rights granted to the journal.

This is an open-access article distributed under the terms and conditions of the Creative Commons Attribution license which permits unrestricted use, distribution, and reproduction in any medium, provided the original work is properly cited. 